\title{
LASERS IN PAEDIATRIC DENTISTRY
}

Lakshmi M. S ${ }^{1}$, Rahul Goyal²

\section{HOW TO CITE THIS ARTICLE:}

Lakshmi M. S, Rahul Goyal. "Lasers in Paediatric Dentistry". Journal of Evolution of Medical and Dental Sciences 2014; Vol. 3, Issue 51, October 09; Page: 11991-11998, DOI: 10.14260/jemds/2014/3582

ABSTRACT: In the past, any surgical procedures of infants and young children was completed under general anesthesia, after obtaining a medical clearance for hospital admission thus consuming lot of time which potentially introduce the child to a greater risk during general anesthesia. Traditionally methods of using scalpels or electro surgery may produce significant post-operative discomfort, requiring sutures -prolonged wound healing. Thus lasers provide simple, significant and safe in office alternative for children.

KEYWORDS: Lasers, General anesthesia, scalpels, discomfort.

INTRODUCTION: Dental lasers have become the well-established instruments in the recent dental practice. There are many researches performed on dental lasers which show its ability to perform less invasive procedures with greater patient comfort which drags the modern practioner towards the laser dentistry.

- Dental lasers offer many advantages in pediatric practices. It has an efficient ability to provide care with less use of needles an high speed hand piece thus making the dental treatment less traumatic for the pediatric age group, at the same time reducing the chances of infection, swelling discomfort and scaring in case of surgical procedures. Lasers Technology in the Dental field became evident, after the introduction of the concept of "Minimum Intervention Dentistry" $[\mathrm{MID}]^{1}$ Lasers fall in the category of "Micro-Dentistry". The use of Lasers was addressed in the "First meeting of World Congress of Micro dentistry (WCM). "Marten's and Simonson" addressed the use of Lasers in Dentistry for the purpose of

- $\quad$ Soft tissue management and

- Hard tissue Diagnosis and management

- Use of Lasers in "Pediatric Dentistry" came into light after its success in Adult Dentistry.

- "Marten's and "Lawrence" in their supportive worke have extremely described the use of Lasers in Pediatric dentistry and published their work in Eur.Journal and DCNA respectively.

- The use of Lasers in pediatric dentistry emphasis the need of "Efficient Behavior management technique and “Child's cooperation level." 2,3

\section{Role of Lasers in Pediatric Dental Patients (Advantages):2,3}

1. Improves children's clinical behavior and cooperation during treatment.

2. Reduces the pain threshold level.

3. Less vibrating action causes pleasable experience.

4. Less traumatic to tissues, because of its focused light.

5. Low heat production than conventional drilling.

6. Many lasers fasten the healing process.

7. Short duration.

8. Lesser patient compliance required. 


\section{REVIEW ARTICLE}

9. Faster action therefore less chair time.

10. Post treatment recovery is fast.

11. No post treatment memory and residual effect

12. Mostly, no Anesthesia required.

13. Can be sued in pediatric patients with needle phobia.

14. Lowers the anxiety of child.

\section{Disadvantages:}

1. Expensive equipment.

2. Technique sensitive.

3. Requires ultra-sensitive handling and sterilization care.

\section{Rationale of using lasers in pediatric dentistry: ${ }^{4}$}

1. To manage soft tissue lesion and hard tissue lesions effectively in a short duration without the need of general anesthesia in young children.

2. For early diagnosis of some hard tissue lesions.

3. For minimally invasive treatment to soft and hard tissues.

\section{Laser physics:5,6}

1. Lasers were first introduced by "Einstein in 1917".

2. Lasers refers to stimulated emission of radiation, which means that stimulated emission must occur if incoming radiation causes emission of radiation within the same properties or wavelength, direction, polarization and phase.

3. Laser light have "photons" in the "same phase, frequency and direction".

4. Every laser has an active medium (eg; atom/molecule) which can be a gas, liquid or solid.

5. The wavelength of laser is determined by its media.

6. Laser light can have four possible interactions with the target tissues depending on its optical property.

a. Transmission.

b. Reflection (for Diagnostic purpose).

c. Absorption (for hard tissue treatment).

d. Scattering (no useful biological effect).

7. Dental therapies are influenced by Different "Absorption coefficients" of the tissues for each particular wavelength.

\section{Fundamentals of Lasers: ${ }^{7}$}

- Lasers are basically based on the composition of "Light".

- Light is a form of "electromagnetic energy" that has Dual nature which included Particle (photon) and Wave.

\section{Wave of photon can be defined by (4) basic properties:}

- Velocity - speed of light.

- Amplitude - Total light of wave oscillation from the top of the peak to the bottom. 
- Wavelength - Distance between two corresponding pointer on the wave.

- Frequency - No. of wave oscillation per sec and it is inversely proposed to wavelength.

- Laser light is different from ordinary light (which is the sum of the visible spectrum (VIBGYOR) diffuse and not found), whereas laser light is one specific color of (VIBGYOR), monochromatic and is highly focused.

- The distinctive features of laser light are:

- Monochromatism - Single color with all energy produced having the same $(\lambda)$ and focused.

- Collimation - Laser light has specific special boundaries, which ensure that laser light has constant beam size and shape that is emitted from source.

- Coherency - All light waves produced by laser are in specific form of electromagnetic energy, having "same amplitude" and "same frequency".

\section{Laser components: ${ }^{8}$}

a) Active medium

a. It is a natural/ manmade material, which when stimulated emits laser light.

b. It can be solid, liquid or gas.

c. Lasers are named based on their active medium.

d. Eg. Solid state laser $\rightarrow$ Nd: YAD.

b) Pumping mechanism

a. It is the source of primary energy which excites the active medium.

b. It is usually a flash light/ arc light.

c) Optical Resonator

a. It is a two mirror system which bounces the laser light back and forth, thus amplifying the power of laser light.

d) Delivery system

a. It depends on the wavelength emitted.

e) Cooling system

a. It may be air/ water.

b. It is used to cool down the heat produced by laser.

f) Control panel

a. It allows variation in power output with time.

\section{Various laser delivery systems: ${ }^{8}$}

1. Hand held laser

2. A flexible hollow wave guide.

3. An articulated arc system.

4. A glass fiber-optic cable.

\section{Lasers introduced for dental applications: ${ }^{9}$}

- For dental tissue management

- $\operatorname{Er:~YAG~}(\lambda=2.94 \mu \mathrm{m}) \rightarrow$ (Erbium: yttrium - aluminium- garnet) 
- Er Cr: YSGG $(\lambda=2.78 \mu \mathrm{m}) \rightarrow$ (Erbium- Chromium: yttrium - scandium - gadolinium garnet)

- $\quad$ Er: YSGG $(\lambda=2.79 \mu \mathrm{m})$

- Oral surgical procedures

- $\quad$ Co2 lasers $(\lambda=9.6 \mu \mathrm{m})$

- Endodontic purposes

- $\quad$ Nd: YAG $(\lambda=1030 \mathrm{~nm}) \rightarrow$ (Modymium: yttrium-aluminium-garnet)

- Periodontal purposes

- ND: YAG

- $\operatorname{KTP}(\lambda=532 \mathrm{~nm}) \rightarrow$ (Potassium - titanium-phosphate)

- Bleaching and soft tissue surgeries

- $\operatorname{KTP}(\lambda=532 \mathrm{~nm})$

- Diagnosis and disinfection

- Diode lasers

- Biostimulation

- Low level laser therapy

Overview of lasers use in pediatric dentistry $4,5,6$
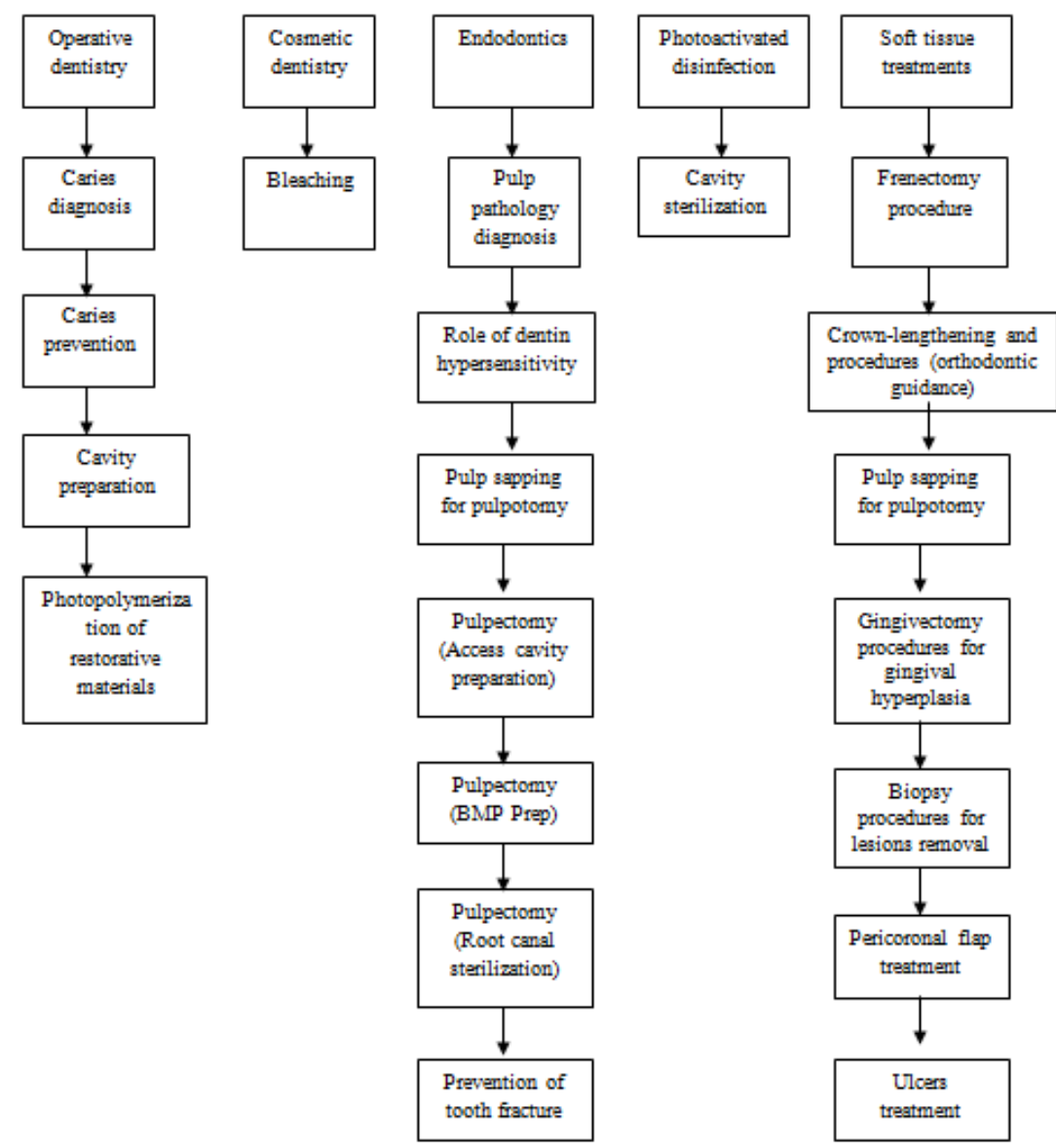

Crown-lengthening and procedures (orthodontic guidance)

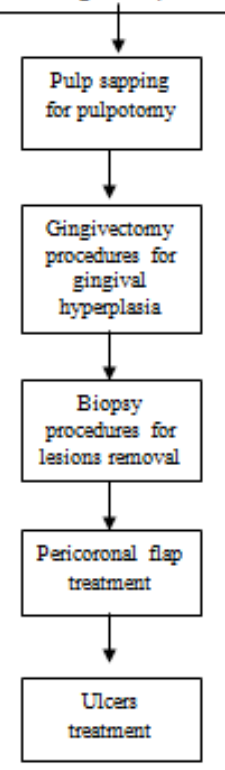




\section{Lasers For Peadiatric Operative Dentistry ${ }^{10,11}$}

\begin{tabular}{|c|c|c|c|c|c|c|c|}
\hline & $\begin{array}{c}\text { Caries } \\
\text { diagnosis }\end{array}$ & & $\begin{array}{c}\text { Caries } \\
\text { prevention }\end{array}$ & & $\begin{array}{c}\text { Cavity } \\
\text { preparation }\end{array}$ & & $\begin{array}{c}\text { Photopolymeriz } \\
\text { ation of } \\
\text { restorative } \\
\text { material }\end{array}$ \\
\hline 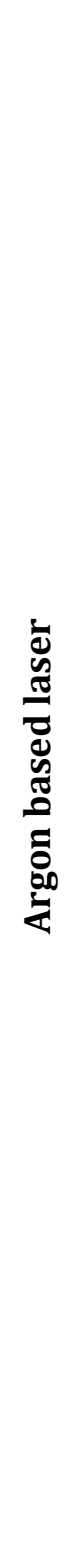 & $\begin{array}{c}\text { Use of Argon } \\
\text { laser } \\
\text { (w/c emitted } \\
\text { Blue-green light } \\
\text { in } 488 \lambda \\
\text { This technique } \\
\text { were named as } \\
\text { - QLF } \\
\text { (Quantitative } \\
\text { light } \\
\text { fluorescent) } \\
\text { DELF (Dye } \\
\text { enhanced } \\
\text { laser } \\
\text { fluorescence) } \\
\text { Both } \\
\text { technique are } \\
\text { based on } \\
\text { diffuse of } \\
\text { organic } \\
\text { component in } \\
\text { human tooth } \\
\text { between } \\
\text { carious and } \\
\text { sound enamel } \\
\text { Both can } \\
\text { diagnose } \\
\text { occlusal and } \\
\text { interproximal } \\
\text { lesions }\end{array}$ & 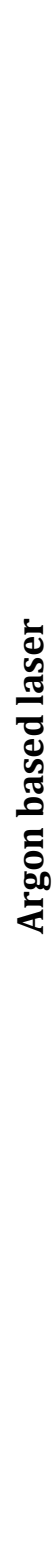 & $\begin{array}{c}\text { Use of Argon } \\
\text { based lasers } \\
\text { only } \\
\text { - } \quad \text { This laaser } \\
\text { can detect } \\
\text { very initial } \\
\text { demineraliz } \\
\text { ation } \\
\text { therefore } \\
\text { they are } \\
\text { used } \\
\text { interms of } \\
\text { - QLF } \\
\text { - DELF }\end{array}$ & 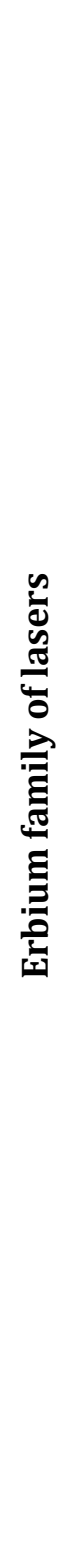 & $\begin{array}{c}\text { Use of Erbium } \\
\text { family of lasers w/c } \\
\text { include } \\
\text { a) Er:YAG } \\
\text { b) Er, Cr:YAG } \\
\text { This lasers can } \\
\text { minimally cut/ } \\
\text { remove the enamel } \\
\text { and dentin } \\
\text { They also cause } \\
\text { complete } \\
\text { bacteriocidal action } \\
\text { They also create } \\
\text { micromechanical } \\
\text { bonding of } \\
\text { restorative and } \\
\text { composite and avoid } \\
\text { need of etching } \\
\text { Also it helps in pit } \\
\text { and fissure } \\
\text { preparation and } \\
\text { better sealing } \\
\text { Adjustment in } \\
\text { microleakage of } \\
\text { composites, due to } \\
\text { better bonding }\end{array}$ & 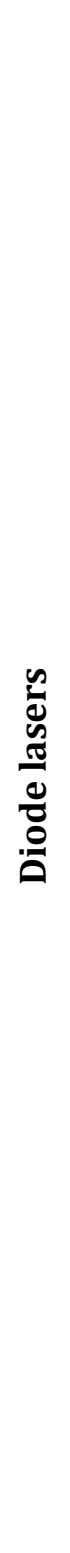 & $\begin{array}{c}\text { Use of Diode } \\
\text { lasers and low } \\
\text { wavelength. } \\
\text { Lasers have been } \\
\text { used for } \\
\text { polymerizing } \\
\text { composite resins }\end{array}$ \\
\hline 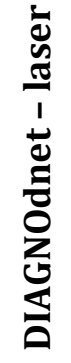 & $\begin{array}{c}\text { Use of } \\
\text { DIAGNODENT } \\
\text { (portable laser) } \\
\text { for detection of } \\
\text { early carious } \\
\text { lesion }\end{array}$ & 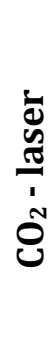 & $\begin{array}{c}\text { Anotin effective } \\
\text { laser is thin } \mathrm{CO}_{2} \\
\text { laser }\end{array}$ & & & 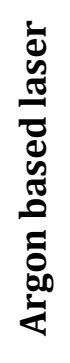 & $\begin{array}{l}\text { Use of Argon } \\
\text { lasers for } \\
\text { composite resin } \\
\text { polymerization }\end{array}$ \\
\hline
\end{tabular}




\section{REVIEW ARTICLE}

\section{Lasers in Paediatric Dentistry12,13,14}

\section{Bleaching of Tetracycline Stains:}

- Tetracycline stains are blue-grey or yellow-brown stain found in children due to consumption of Tetracycline by Mothers during pregnancy, when this is active tooth development of fetus.

- Tetracycline stain can be managed by either.

\begin{tabular}{|c|c|}
\hline $\begin{array}{c}\text { Extracoronal bleaching } \\
\text { (Superficial removal of enamel surface) }\end{array}$ & $\begin{array}{c}\text { Intracoronal bleaching } \\
\text { (Post-interventional RCT) }\end{array}$ \\
\hline Argon laser & KTP \\
$\mathrm{CO}_{2}$ laser & Laser \\
Diode laser & (Family of Nd: YAG laser) \\
\hline
\end{tabular}

\section{Lasers for photoactivated disinfection for the purpose of cavity Disinfection:}

- Photo activated disinfection (PAD) is a method of disinfecting the Decayed cavity and ideal (MID) approach

- First a solution is placed once the decayed cavity, which is then activated Using (PAD) laser. This causes release of nascent $\mathrm{O}_{2}$ that kills all bacteria and sterilizes the cavity

- Lasers used for activating solution of (PAD) are:

- KTP

- Nd: YAG

- Diode laser

\section{Lasers for soft tissue management ${ }^{15}$}

- For frenectomy procedures (Tongue Tie/Ankyloglosia): Er:YAG or Er, Cr:YSGG

- Exposure of teeth for orthodontic guidance: Er:YAG or Er, Cr: YSGG

- For Gingivectomics/ Gingival countering incase of phenytoin gingival enlargement in children with convulsive disorders $\rightarrow$ Er: YAG or Er, Cr: YSGG or $\mathrm{Co}_{2}$ Laser

- For removal of lesions for the purpose of biopsies

- Pigmented lesion (Nd: YAG or Diode or Argon)

- Non-pigmented lesions (Co2 lasers)

- For pericoronal flap removal $\rightarrow$ Er: YAG or Er, Cr: YSGG

- For treatment of apthous ulcers $\rightarrow$ Nd: YAG or Er: YAG or herpetic lesions

\section{Role of $\mathrm{Co}_{2}$ - lasers as a better choice for soft tissue management in children $\mathbf{1 6}$}

1. Have ability to coagulate and seal ruptured blood vessel.

2. Vaporize the tissue.

3. Antimicrobial property.

4. Precise incision (due to increasingly focused beam).

5. Minimal post treatment and swelling.

6. Less vibratory action.

7. Enhanced healing. 
Lasers for paediatric endodontics (Vital pulp therapies in primary and young permanent teeth) ${ }^{17}$

- Pulp pathology diagnosis

- Diode laser (Diagnodent)

- Laser Doppler flowmetry

- Treatment of dentinal hypersensitivity

- Low level laser therapy (LLLT)

- Diode laser

- For pulpotomies procedure

- For Deroofing of pulp chamber

(Er: YAG) or Er, Cr: YSGG)

- For haemostasis over radicular pulp

$\mathrm{Nd}$ : YAG laser) -

Co2 Laser

Low level laser therapies (LLLT) are preferred now a day because of their property of "Biostimulation"

\section{Lasers for Paediatric endodontics (non-vital pulp therapy/ Pulpectomy) ${ }^{17}$}

Lasers can be used for managing various procedures of pulpectomy viz:

- Access cavity preparation (Ef: YAG or Er, Cr: YSGG or Er, Cr: YAG).

- Biomechanic preposition (Eg: YAG/ Nd: YAG).

- Root canal sterilization ( $\mathrm{CO}_{2}$ Lasers, Diode laser, KTP laser).

- Root canal obturation.

\section{REFERENCES:}

1. Lasers Restorative Dentistry in Children and Adolescents G Olivi, MD Genovese. Dept of Endodontics University of Genoa DI.S.T.BI.M.O, Private Practice of Pediatric Dentistry and Orthodontics Rome, Italy.

2. Genovesese MD, Olivi G. Lasers in Paediatric Dentistry; Patient Acceptance of Hard and Soft Tissue Therapy. European Journal of Paediatric Dentistry 2008, March 9 (1); 13-7.

3. The Dental Clinics Of North America: Lasers In Clinical Dentistry (October 2004 - Volume 48 Number 4)

4. Coluzzi D. Fundamentals of Dental Lasers: Science and Instruments. Dent Clin North Am 2004; 48 (4): 751-70.

5. Olivi G, Genovese MD, Caprioglio C. Evidence-Based Dentistry On Laser Paediatric Dentistry: Review And Out-Look. Eur J Paediatr Dent 2009; 10 (1): 29-40.

6. Laser Physics and Review of Laser Applications in Dentistry for Children. Europaen Archieves Of Paediatric Dentistry, April 2011, Vol 12, Issue 2, Page 61-67.

7. Scientific Review, Fundamentalals of Lasers in Dentistry; Basic Science, Tissue Interaction and Instrumentation. Donald J Coluzzi Dds, Portola Valley, California. Journal Laser of Dentistry 2008; 16 Specal issue; 4-10.

8. LASERS in Dentistry; an Over View Donald J Coluzzi DDS, Alan J Goldstein, DMD Wednesday March 31, 2004. 


\section{REVIEW ARTICLE}

9. Lasers and Its Clinical Applications in Dentistry; Mahavir. B. Mishra, Shanu Mishra International Journal of Dental Clinics 2011: 3 (4): 35-38.

10. . Matsumoto K, Hossain M, Hossain MM, Kawano H, Kimura Y. Clinical Assessment of Er, Cr: YSGG Laser Applications For Caries Removal And Cavity Preparation In Children. Med Laser Appl 2002; 20 (1): 17-21.

11. Tanboga I, Eren F, Altinok B, Peker S, Ertugal F. The Effect of Low Level Laser Therapy on Pain during Cavity Pre-Paration with Laser in Children. Eur Arch Paediatr Dent 2011; 12 (2): 93-5.

12. Whitters CJ, Hall A, Creanor SL, Et Al. A Clinical Study of Pulsed Nd: YAG Laser Induced Pulpal Analgesia. J Dent 1995; 23 (3): 145-50 Lasers and Padistric Dentistry. General Dentistry Article Nov 2008.

13. Policy on the use of Lasers for Pediatric Dental Patients; Aapd-2013.

14. Soft and Hard Tissue Management Using Lasers in Esthetic Restoration. Hughd, Flaxdds. Dental Clinics of North America Vol 55, Issue 2 Pages 383-402, April-2011.

15. Human Primary Pulpal Tissue. Robert D Elliot, DMD, MS, Micheal W Roberts, DDS, MSC D. Aapd $21 ; 6 ; 1999,327-331$.

16. Evaluation Of The C02 Lasers On Vital Human Primary Pulpal Tissue.Robert D Elliot, DMD, MS, Michael W Roberts, DDS, MSC D.

17. Low-Level Laser Therapy For Pulpotomy Treatment Of Primary Molars M. Vahid Golpayegani 1, G. Ansari, N. Tadayon, Sh. Shams, M. Mir.

\section{AUTHORS:}

1. Lakshmi M. S.

2. Rahul Goyal

\section{PARTICULARS OF CONTRIBUTORS:}

1. Ex Post Graduate Student, Department of Paediatric Dentistry, JSS Dental College \& Hospital, Mysore, Karnataka.

2. Ex Post Graduate Student, Department of Paediatric Dentistry, JSS Dental College \& Hospital, Mysore, Karnataka.

\section{NAME ADDRESS EMAIL ID OF THE CORRESPONDING AUTHOR:}

Dr. Lakshmi M. S, \#2453, $4^{\text {th }}$ Cross, Marigowda Layout, Prashanth Nilaya, Mandya-01, Karnataka, India. Email: drlaxmiprashanth@gmail.com

Date of Submission: 17/09/2014. Date of Peer Review: 18/09/2014. Date of Acceptance: 01/10/2014. Date of Publishing: 08/10/2014. 